\title{
Dynamic simulation of crop rotations to evaluate the impact of different nitrogen management strategies on water quality in Southland, New Zealand
}

\author{
E.N. Khaembah, R. Cichota, R. Zyskowski and I. Vogeler \\ The New Zealand Institute for Plant and Food Research Limited, Private Bag 4704, Christchurch, 8140, \\ New Zealand
}

Email: edith.khaembah@plantandfood.co.nz

\begin{abstract}
Nitrogen lost from agricultural fields is one of the main causes of water pollution. In New Zealand, the National Policy Statement for Fresh Water Management authorises Regional councils to administer limits around the amount of nitrogen discharged into water systems. Enforcement of this policy requires reliable ways to quantify nitrogen losses from land uses in catchments and test future land use options for minimising those losses while maintaining farm profitability. Since measurement of nitrogen loss under field conditions can be technically challenging and costly, simulation models have often been relied on to provide this information.
\end{abstract}

The evaluation of environmental impacts from agricultural activities at a catchment scale requires integration of modelling tools designed to work at different levels. A dynamic farm systems model is needed in this context, to capture the impacts of land use changes and management decisions on water and nitrogen fluxes in the soil-plant interface. Generated information from this level can then be scaled up by hydrological models to determine the impact of farming activities at the catchment and regional scales. In this work, we used the Agricultural Production Systems sIMulator (APSIM), a process-based farm systems model, to evaluate the effect of fertiliser nitrogen management on crop production and nitrogen leaching from cropping rotations in the Southland region of New Zealand. For this, we developed a general simulation that can be modified with relatively simple inputs to describe a variety of farming systems typical of the region. We test and demonstrate this abstraction using simulations of three rotations (continuous wheat, pasture-wheat-grain oats, and wheat-green oats-fodder beet-peas, hereafter, Rotation 1, Rotation 2 and Rotation 3, respectively) modelled for 35 years (1980-2015). Two fertiliser management options were evaluated for each crop rotation: scheduled management where fertiliser nitrogen rates and timing of application used a prescribed schedule, and soil-test management where fertiliser nitrogen rates and timing were based on the analysis of simulated soil nitrogen levels within a specified time period.

Results indicated APSIM-estimated crop yields were within yield range for the region, and nitrogen fertiliser management had a negligible effect on crop yield. The estimated average nitrogen fertiliser applied to crops under the soil-test management was either similar or lower (by $11-12 \%$ ) than nitrogen fertiliser applied under the scheduled management. The soil test management also resulted in similar or lower (17-32\%) nitrogen leaching than the scheduled management (Fig. 1). These results fundamentally show that soil-test based fertiliser application has the potential to increase fertiliser nitrogen use efficiency and reduce the risk of nitrogen loss to the Southland catchment water systems. These results also demonstrate the capability of our APSIM setup to produce realistic crop production levels and account for intraand inter-season variability in soil nitrogen and weather conditions. Using such simulation setup is a promising tool to generate valuable data to assist in assessing the productivity and environmental effects of cropping systems and alternative management options for nitrogen mitigation to improve water quality.

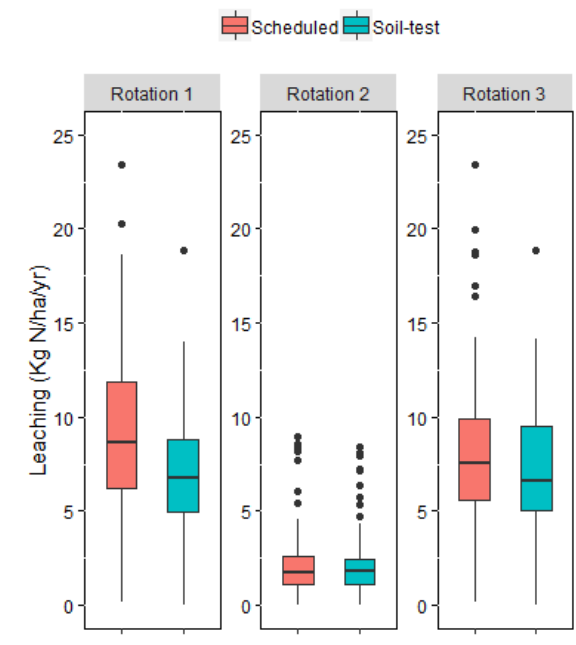

Figure 1. APSIM-estimated nitrogen leaching for two fertiliser management and three crop rotations.

Keywords: Integrated modelling, nitrogen management, water quality 


\section{INTRODUCTION}

Nitrogen loss from intensive agriculture is one of the main causes of surface and groundwater systems (Beman et al. 2005; Dymond et al. 2013; Giles 2005; Heisler et al. 2008), and many central and local governments have formulated environmental policies to protect water systems from nitrogen contamination. In New Zealand, for example, the Ministry for the Environment published the National Policy Statement for Fresh Water Management (Freshwater NPS 2014) which requires regional councils to administer a policy around limits of nitrogen discharge into water systems. Enforcement of this policy requires reliable ways to quantify nitrogen losses from land uses in catchments and test future land use options for mitigating those losses. Simulation models have often been relied on to provide this information because of the high costs and challenges associated with measuring nitrogen loss under field conditions (Cichota et al. 2010; Monaghan and de Klein 2014; Langeveld et al. 2007).

There is typically a strong physical connection between surface and ground water in a catchment. Therefore, integrated analyses of nitrogen and water flows through the landscape and between the surface and ground water systems are crucial in the assessment of effective measures to improve water quality (Elliott et al. 2016; Peckham et al. 2013). One way to facilitate such analyses is to integrate complementary modelling tools through an infrastructure (framework) that enables various models of water quality to interoperate. A dynamic farm systems model is needed in this context, to capture the effects of land use changes and management decisions on water and nitrogen fluxes among the soil, vegetation and atmosphere. Generated information can then be passed to hydrological models to integrate the effects and scale-up the impact of land use changes on water quality at the catchment level. Given the complexity and variability of farming systems and their management, simplifications are often required when simulating whole catchments and future scenarios. To ensure the robustness of predictions, these simplifications have to be well grounded and tested.

This study used farm systems modelling to evaluate crop rotations for a catchment located in the south western Southland region of New Zealand. A baseline simulation was set up with a variety of crops and management options based on local statistics and good practice recommendations. This simulation can be modified with relatively simple inputs, enabling the model to describe a variety of farming systems typical of the region. The objectives for this work were to (i) verify the model performance for predicting production levels, and (ii) use the model to estimate nitrogen losses from different land uses, and evaluate mitigation options to minimise those losses.

\section{MATERIALS AND METHODS}

\subsection{Description of the study area}

The Aparima catchment is located in south western Southland region and covers an area of $1375 \mathrm{~km}^{2}$ (Environment Southland 2017). The catchment is predominantly cultivated land mainly in pasture to support sheep, dairy and beef cattle, with arable and forage crops grown on a small-scale (Journeaux and Wilson 2014). Crops are important for dairy feeding, and farmers often utilise $12-20 \%$ of their productive land to grow forage crops in the region (Chakwizira and de Ruiter 2009; Monaghan et al. 2010). Crops sown in the catchment include wheat, barley, oats and fodder beet (Legard 2015; StatsNZ 2018). The catchment was selected for this study because it has previously undergone economic and environmental analysis of land use change (Journeaux and Wilson 2014). Water quality information from five sites in the catchment showed algal growths and a progressive decline in macroinvertebrate health indices (LAWA 2019).

The work conducted in this study aims to contribute to on-going initiatives, such as the Aparima Freshwater Management (Aparima Community and Environment) project, a community-led multi-agency venture formed to promote good land use across the catchment as well as improve water quality and other environmental outcomes for the community.

\subsection{Modelling tool and simulation setup}

The model used in this study is the next generation Agricultural Production Systems sIMulator (APSIM). APSIM is a dynamic model containing daily time-scale nutrient and soil water modules that allow continuous simulation of changes in nitrogen and water status in response to weather, management and crop uptake (Holzworth et al. 
2018). Simulations were based on three representative crop rotations (Fig. 2) developed using information from a resident farmer, the Foundation for Arable Research, and New Zealand statistics data (StatsNZ 2018). Crop rotations were simulated for 35 years (1980-2015) broken into15-year runs with a 5-year offset i.e. 1980-1995, 1985-2000, 1990-2005, 1995-2010, 2000-2015. Simulations were set up using climate data for a location close to the middle of the catchment; these were obtained from the Virtual Climate Station Network (NIWA 2019; Tait and Turner 2005; Tait et al. 2006). The soil was defined as a deep silt loam (Typic Firm Brown Soil), based on data obtained from the New Zealand Soils database (Wilde 2003), complemented with pedo-transfer functions (Cichota et al. 2013). The outputs evaluated included individual crop yields, nitrogen fertiliser use, and nitrogen leaching accumulated annually from 15 March to 14 March. Two fertiliser management options were analysed for each crop rotation: (i) scheduled management (hereafter, scheduled) where fertiliser nitrogen rates and timing of application used a prescribed schedule and (ii) soil test management (hereafter, soil-test) where fertiliser nitrogen rates and timing were based on the analysis of simulated soil nitrogen levels within a specified time period. The fertiliser nitrogen rates and timing for the scheduled management were guided by information from three Canterbury farms that participated in a 6-year nitrogen leaching mitigation project (Khaembah and Horrocks 2018) and research-based recommendations (Morton et al. 2012 and 2017).

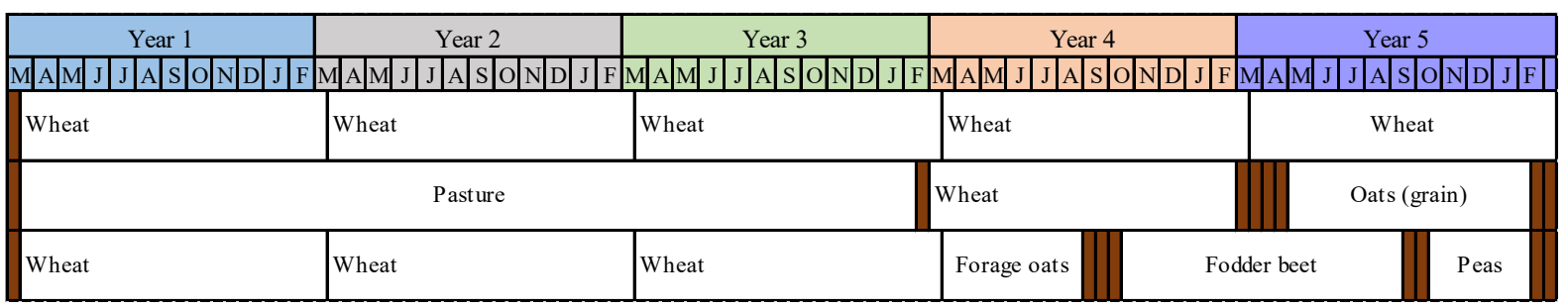

Figure 2. Three crop rotations from the Aparima catchment. Fallow periods ranging from half to two months are indicated by brown cells. Each brown cell represents half a month.

It was assumed, for simplicity, that no nitrogen was returned as manure or urine. Pasture was managed under the cut and carry regime (with harvests triggered based on standing biomass). Forage oats were chopped and fodder beet lifted, and both were assumed to be fed off-paddock.

\section{RESULTS AND DISCUSSION}

Results indicate a wide range in crop productivity (Table 1) reflecting the effect of inter-annual climate variability on crop growth. Model-estimated crop yields were within range of regional historical farm data (Millner et al. 2013; StatsNZ 2018) and research findings (Chakwizira et al. 2014; DairyNZ 2018). Apart from grain oats in rotation 2, where yield was greater under scheduled than soil-test fertiliser management, the model indicated negligible yield differences between the nitrogen fertiliser management options (Fig. 3).

Under both fertiliser managements options, green oats were used as a catch crop and received no nitrogen fertiliser, while peas received $50 \mathrm{~kg} \mathrm{~N} / \mathrm{ha}$ (Table 1) at sowing. For the rest of the crops, the estimated nitrogen fertiliser inputs under the soil-test management were comparable with or lower than scheduled nitrogen inputs (Table 1). Across rotations and crops, there was wide variation in applied nitrogen under soil-test management, reflecting the dynamic in-season fertiliser application response to temporal variability in soil nitrogen supply. Substantial differences in nitrogen input were observed for wheat in rotations 1 and 3, with the model estimating, on average, 11-12\% lower applied nitrogen fertiliser under soil-test than scheduled management (Table 1). For these wheat crops, dry matter production per unit of applied nitrogen (fertiliser nitrogen use efficiency) was $6 \%$ greater under soil-test than scheduled management.

As expected, estimated average nitrogen leaching generally was lower under soil-test management than scheduled management. This difference was evident in rotation 1 and rotation 3, with rotation 2 exhibiting minimal leaching that was similar between the two fertiliser managements (Fig. 4). On average, soil-test management reduced nitrogen leaching by 32 and $17 \%$ in rotation 1 and rotation 3 , respectively. 


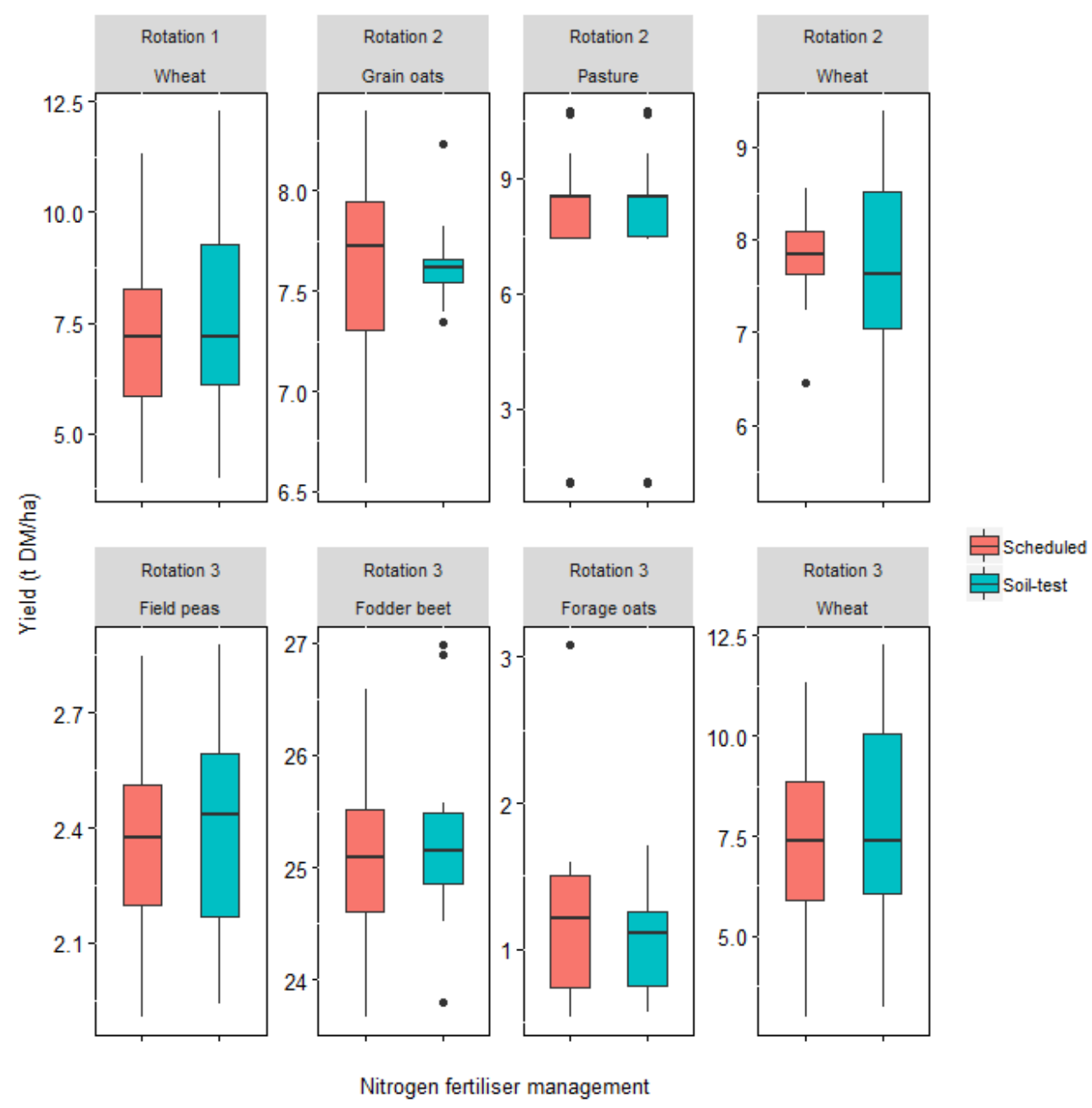

Figure 3. Dry matter (DM) yield estimated by the Agricultural Production Systems sIMulator (APSIM) for two fertiliser managements and three crop rotations of the Aparima catchment, Southland, New Zealand.

Table 1. Nitrogen fertiliser applied to crops in rotation. The scheduled rates were fixed model inputs while soiltest rates were estimated by the Agricultural Production Systems sIMulator (APSIM) model based on daily soil testing. Values in the parentheses represent the range.

\begin{tabular}{|l|l|l|l|}
\hline \multirow{2}{*}{ Rotation } & \multirow{2}{*}{ Crop } & Nitrogen fertiliser management \\
\cline { 3 - 4 } & & Scheduled & Soil-test \\
\hline 1 & Wheat & 250 & $220(120-330)$ \\
\hline \multirow{3}{*}{2} & Wheat & 250 & $242(150-300)$ \\
\cline { 2 - 4 } & Grain oats & 180 & $180(150-210)$ \\
\cline { 2 - 4 } & Pasture & 150 & 150 \\
\hline \multirow{3}{*}{3} & Wheat & 250 & $223(90-330)$ \\
\cline { 2 - 4 } & Forage oats & 0 & 0 \\
\cline { 2 - 4 } & Fodder beet & 160 & $50(142-182)$ \\
\cline { 2 - 4 } & Field peas & 50 & \\
\hline
\end{tabular}




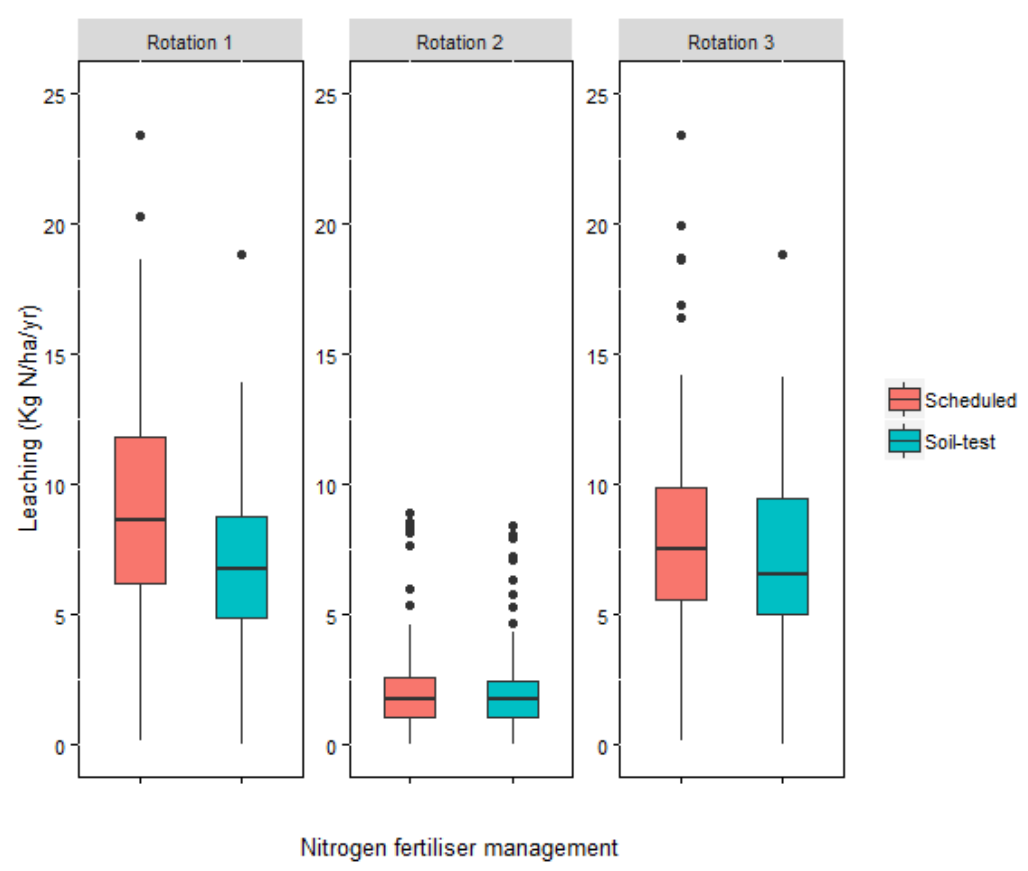

Figure 4. Nitrogen leaching estimated by the Agricultural Production Systems sIMulator (APSIM) for two fertiliser managements and three crop rotations of the Aparima catchment, Southland, New Zealand.

These model-estimated outputs largely show that soil-test-based fertiliser application has the potential to increase fertiliser nitrogen use and reduce the risk of nitrogen loss to the water systems in the Aparima catchment. Testing the soil to determine the amount of nitrogen fertiliser needed by a crop over the season is recommended and information is readily available for New Zealand farmers (e.g. Morton et al. 2012 and 2017). However, the regularity of soil testing and the splits of nitrogen fertiliser application differ from farmer to farmer. In general, soil tests are performed 1-3 times over spring and small amounts of nitrogen applied pre- or at-sowing followed by 2-3 large top-dressings during vigorous crop growth (Auld R, pers comm.). Depending on soil type and climate, application of nitrogen in large amounts can increase the risk of nitrogen leaching.

The continuous testing of the soil and fertiliser application depicted under the soil-test management in this study is potentially a better method than the traditional soil-test method where results from representative paddocks are extrapolated to similar areas of the farm, e.g. paddocks with similar soil type (Morton et al. 2012 and 2017). The APSIM model is capable of simulating individual paddocks (or sections of those paddocks) and can therefore, account for field and temporal variability in soil nitrogen status. As demonstrated by this study, generic crop rotations abstracted from actual farming system can produce realistic estimates of average production levels and include inter-annual variability. The effects of different fertiliser management and the estimated nitrogen inputs for the two scenarios tested were also in line with expectations. Thus, the use of such simulation setup is a promising tool to generate valuable data to help assess productivity and environmental effects of cropping systems and nitrogen mitigation options to improve water quality. Future work will focus on expanding the tests and integrating APSIM simulations with hydrology modelling via an inter-operable modelling framework to simulate water quality at the catchment level.

\section{ACKNOWLEDGEMENTS}

Research was completed under the Interoperable Models Programme funded by the Our Land and Water National Science Challenge and Plant \& Food Research's Sustainable Agro-ecosystems (SAE) programme, with funding from the Strategic Science Investment Fund (SSIF). 


\section{REFERENCES}

Beman, J.M., Arrigo, K.R. and Matson, P.A. (2005). Agricultural runoff fuels large phytoplankton blooms in vulnerable areas of the ocean. Nature, 434(7030), 211-214.

Chakwizira, E. and de Ruiter J. (2009). Southland winter feeding program: Evaluation of Options, Plant and Food Contract Report 50pp, The New Zealand Institute for Plant and Food Limited, Lincoln, New Zealand.

Chakwizira, E., de Ruiter, J.M. and Maley, S. (2014). Growth, nitrogen partitioning and nutritive value of fodder beet crops grown under different application rates of nitrogen fertiliser. New Zealand Journal of Agricultural Research, 57(2), 75-89.

Cichota, R., Brown, H., Snow, V.O., Wheeler, D.M., Hedderley, D., Zyskowski, R. and Thomas, S. (2010). A nitrogen balance model for environmental accountability in cropping systems. New Zealand Journal of Crop and Horticultural Science, 38(3), 189-207.

Cichota, R., Vogeler, I., Snow, V.O. and Webb, T.H. (2013). Ensemble pedotransfer functions to derive hydraulic properties for New Zealand soils. Soil Research, 51(2), 94-111.

DairyNZ (2018). Average pasture growth data by region. https://www.dairynz.co.nz/average-pasture-growth.

Dymond, J.R., Ausseil, A.G., Parfitt, R.L., Herzig, A. and McDowell, R.W. (2013). Nitrate and phosphorus leaching in New Zealand: a national perspective. New Zealand Journal of Agricultural Research, 56(1), 4959.

Elliott, A.H., Semadeni-Davies, A.F., Shankar, U., Zeldis, J.R., Wheeler, D.M., Plew, D.R., Rys, G.J. and Harris, S.R. (2016). A national-scale GIS-based system for modelling impacts of land use on water quality. Environmental Modelling \& Software, 86, 131-144.

Environment Southland (2017). The Southland region. https://www.es.govt.nz/community/aboutsouthland/Pages/default.aspx.

Freshwater NPS (2014). National Policy Statement for Freshwater Management 2014. http://www.mfe.govt.nz/publications/fresh-water/national-policy-statement-freshwater-management-2014.

Giles, J. (2005). Nitrogen study fertilizes fears of pollution. Nature, 433(7028), 791-791.

Heisler, J., Glibert,.P.M., Burkholder, J.M., Anderson, D.M., Cochlan, W., Dennison, W.C., Dortch, Q., Gobler, C.J., Heil, C.A., Humphries, E. and others. (2008). Eutrophication and harmful algal blooms: A scientific consensus. Harmful Algae, 8(1): 3-13.

Holzworth, D., Huth, N.I., Fainges, J., Brown, H., Zurcher, E., Cichota, R., Verrall, S., Herrmann, N.I., Zheng, B. and Snow, V. (2018). APSIM Next Generation: Overcoming challenges in modernising a farming systems model. Environmental Modelling \& Software, 103, 43-51.

Journeaux, P. and Wilson, K. (2014). Economic analysis of the impact on farming of limiting the loss of nitrogen and phosphorus: A Catchment Case Study: Aparima (Southland). MPI Technical Paper No: 2014/20, 78pp, https://www.mpi.govt.nz/dmsdocument/4149/send.

Khaembah, E.N. and Horrocks, A. (2018). A modelling approach to assessment and improvement of nitrogen management on New Zealand arable farms: a case study. Paper presented at the $48^{\text {th }}$ Agronomy New Zealand conference, Twizel, New Zealand, November 6-8.

Langeveld, J.W.A., Verhagen, A., Neeteson, J.J., van Keulen, H., Conijn, J.G., Schils, R.L.M. and Oenema, J. (2007). Evaluating farm performance using agri-environmental indicators: Recent experiences for nitrogen management in The Netherlands. Journal of Environmental Management, 82(3), 363-376.

LAWA (2019). Land, Air, Water Aotearoa - The Aparima river. https://www.lawa.org.nz/explore-data/southlandregion/river-quality/aparima-river/.

Legard, G. (2015). An inventory of nitrogen and phosphorous losses from rural land uses in the Southland region. Paper presented at the $28^{\text {th }}$ Annual Fertilizer and Lime Research Centre worshop, Massey University, Palmerston North, New Zealand, February 10-12.

Millner, J.P., Roskruge, N.R. and Dymond, J.R. (2013). The New Zealand arable industry, Ecosystem services in New Zealand: conditions and trends, 13pp. Manaaki Whenua Press, Lincoln, New Zealand.

Monaghan, R.M., Semadeni-Davis, A., Muirhead, R.W., Elliot, S, and Shankar, U. (2010). Land use and land management risks to water quality in Southland, 85pp. Environment Southland.

Monaghan, R.M. and de Klein, C.A.M. (2014). Integration of measures to mitigate reactive nitrogen losses to the environment from grazed pastoral dairy systems. Journal of Agricultural Science, 152, S45-S56.

Morton, J., Stafford, A, and Roberts, A. (2017). Fertiliser use on New Zealand forage crops, 32pp. Fertiliser Association of New Zealand.

Morton, J., Craighead, M. and Stevenson, K. (2012). Managing soil fertility on cropping farms, 68pp. Fertiliser Association of New Zealand.

NIWA (2019). Climate database-NIWA. http://cliflo.niwa.co.nz/ [Accessed May 2019].

Peckham, S.D, Hutton, E.W.H. and Norris, B. (2013). A component-based approach to integrated modeling in the geosciences: The design of CSDMS. Computers \& Geosciences, 53, 3-12.

StatsNZ (2018). Agricultural production statistics. https://www.stats.govt.nz/information-releases/agriculturalproduction-statistics-june-2017-final. 
Tait, A. and Turner, R. (2005). Generating multiyear gridded daily rainfall over New Zealand. Journal of Applied Meteorology, 44(9), 1315-1323.

Tait, A., Henderson, R., Turner, R. and Zheng, X.G. (2006). Thin plate smoothing spline interpolation of daily rainfall for New Zealand using a climatological rainfall surface. International Journal of Climatology, 26(14), $2097-2115$.

Wilde, R.H. (2003). Manual for National Soils Database. Landcare Research, Palmerston North, New Zealand. Pp. 53. 